\title{
Do relevant markers of cancer stem cells CD133 and Nestin indicate a poor prognosis in glioma patients? A systematic review and meta-analysis
}

Bin $\mathrm{Wu}^{\dagger}$, Caixing Sun ${ }^{\dagger}$, Fang Feng ${ }^{\dagger}$, Minghua Ge and Liang Xia ${ }^{*}$

\begin{abstract}
Background: CD133 and Nestin, as the markers of cancer stem cells, have recently been reported frequently in the pathogenesis and development of human gliomas. However, the prognostic role of CD133 and Nestin in gliomas still remains controversial. In this study, we aimed to evaluate the association between the expression of CD133 and Nestin and the outcome of glioma patients by conducting a systematic review and meta-analysis.

Methods: We performed systematically electronic and manual searches through the database of Pubmed and embase (until to December 25, 2014) for titles and abstracts which investigated the relationships between CD133 and Nestin expression and outcome of glioma patients. A systematic review and meta-analysis was executed to generate Pooled hazard ratios (HRs) with $95 \%$ confidence intervals (Cls) for overall survival (OS) and progression-free survival (PFS).

Results: A total of 1,490 patients from 32 studies (13 articles) were included in the analysis. 19 studies and 13 studies investigated correlation between CD133 expression or Nestin and survival in gliomas, respectively. Our results showed that high CD133 expression in patients with glioma was associated with poor prognosis in terms of OS (HR 1.69; $95 \% \mathrm{Cl}, 1.16-2.47 ; \mathrm{P}=0.0060)$ and PFS (HR, 1.64; $95 \% \mathrm{Cl}, 1.12-2.39 ; \mathrm{P}=0.010)$. In addition, high Nestin expression were associated with worse OS (HR 1.751; $95 \% \mathrm{Cl}, 1.19-2.58, \mathrm{p}=0.004$ ) but has no significant association with PFS (HR 1.55; $95 \% \mathrm{Cl}, 0.96-2.51, \mathrm{p}=0.074)$. Even more important, the results of the subgroup meta-analyses show that that high CD133 expression was associated with worse prognosis in terms of OS and PFS in patients with WHO IV glioma but not WHO II-III. On the other hand, Nestin high expression was associated with worse prognosis in terms of OS and PFS in patients with WHO II-III glioma but not WHO IV.

Conclusion: High level of CD133 expression trends to correlate with a worse OS and PFS in glioma patients, especially WHO IV gliomas and Nestin high expression trends to correlate with a worse OS in glioma patients especially WHO II-III, revealing both the markers of cancer stem cells may as the potential pathological prognostic markers for glioma patients.
\end{abstract}

Keywords: CD133, Nestin, Prognosis, Glioma

\footnotetext{
* Correspondence: xialiang@zjcc.org.cn

${ }^{\dagger}$ Equal contributors

Zhejiang Cancer Hospital, 38 Guangji Road, Hangzhou, Zhejiang Province

310022, China
} 


\section{Introduction}

Glioma is the most common primary brain tumor with the most grade malignancy, although in recent years the diagnosis and treatment of gliomas have made great progress, the prognosis of patients with glioma remains poor [1]. There is an urgent need to find a reliable marker to predict the prognosis of glioma, thereby providing the basis for the choice of a reasonable individualized treatment plan [2].

Cancer stem cell theory considers that the occurrence of tumors derives from some special cells, these cells are called cancer stem cells with the similar characteristics to embryonic stem cells, such as selfrenewing and unlimited proliferation, multi-directional differentiation and anti-chemoradiotherapy and so on $[3,4]$. Due to these characteristics of cancer stem cells, the traditional treatments, such as radiation and chemotherapy, can not effectively remove the cancer stem cells, the remaining tumor stem cells continue proliferation and differentiation, leading to tumor recurrence $[4,5]$. There are a variety of markers used to isolate glioma stem cells, CD133 and Nestin are the most commonly used two markers that are widely expressed in various tumor cells, such as malignant glioma, liver cancer, ovarian cancer, colon cancer, lung cancer, etc. [6-11]. In recent years, a number of studies analyze the relationship between the markers of tumor stem cells CD133, Nestin and prognosis of patients with glioma, but due to differences in research method, sample size and the study population, the findings of a single sample are difficult to extend to the entire population and the obtained conclusions are inconsistent. This study used Meta-analysis method to systematically evaluate the literatures on the relationship between the expression of Nestin, CD133 that were multiple markers involving glioma stem cells and the prognosis of patients with glioma.

\section{Materials and methods}

Search strategy and study selection

A systematic literature search of the PubMed and Embase databases was conducted on studies evaluating the effect of the markers of cancer stem cells (CD133 and Nestin) on glioma patient survival. Our search strategy included terms ("Glioma" or "Glioblastoma") and ("CD133 antigen" or "AC133 antigen" or "prominin-1" or "PROML1" or "Nestin") and ("Survival" or "Mortality" or "Prognosis"). The literature search was conducted in 25 December 2014 and updated in 5 January 2015. Furthermore, a manual search of reference lists from the relevant original articles and review articles was also performed for additional relevant publications.

Two independent reviewers (Xia $\mathrm{L}$ and $\mathrm{Wu} \mathrm{B}$ ) independently inspected all candidate articles. Discrepancies were resolved by discussion. Studies that met all the following inclusion criteria were included in the review: (i) The diagnosis of glioma was made based on pathological examination; (ii) The association of the expression CD133 or Nestin with OS or PFS about gliomas was reported; (iii) The study provided the direct estimation of hazard ratios (HRs) and there was $95 \%$ confidence intervals (CIs), or the date could be calculated by $p$ values and other data reported. (iv) We included the studies with the largest sample size if the same glioma patient population were found to overlap among publications.

\section{Definitions and data extraction}

The OS (overall survival) was defined as the time interval between the medical treatment and the death of patient or the last follow-up. The PFS (progression free survival) was calculated as the time interval between the date of treatment and the detection of the tumor recurrence or death from any cause. Both two reviewers independently carried out data extraction from including studies and any discrepancies were resolved by discussion between the two. The following data were extracted from all including studies: the first author's name, year of publication, country, sample size, patient age, WHO grade, detect method of CD133 or Nestin expression, cut-off level, follow up period, survival analysis and prognostic outcomes (PFS and OS). Any discrepancies were resolved through discussion amongst the authors.

\section{Quality assessment of primary studies}

Quality assessment of included primary studies was independently executed by two reviewers (Xia L and Wu B) using the Newcastle-Ottawa Quality Assessment Scale (NOS). NOS scores of $\geq 6$ were defined as high-quality studies. Any disagreement was determined by joint discussion.

\section{Statistical analysis}

All analyses were performed by using stata 12.0 statistical software (Stata Corporation, College Station, TX, USA). Hazard ratio (HR) and $95 \%$ confidence intervals (CI) were got directly from each study or from estimation of Kaplan-Meier survival curves according to the methods by Parmer et al. An HR less than one was defined as a better prognosis in glioma patients with IDH mutation, whereas an HR more than one indicated a poor prognosis. We the most powerful one (multivariate analysis was superior to univariate analysis. And the latter one weighted over unadjusted Kaplan-Meier analysis) was chose, if several HR estimates were presented in the same study.

The heterogeneity of the included trials was assessed by the Cochrane's Q statistic for each meta-analysis. We carried out both fixed-effects (Mantel-Haenszel method) 
and random effects (DerSimonian-Laird method) models and producted the pooled HRs. Thanks to a priory of assumptions about the likelihood of heterogeneity across primary studies, the random-effects model was chosen. In addition, subgroup analyses were performed to investigate the potential causes of heterogeneity according to study country, sample size, patient age, follow-up period, detect method of CD133 or Nestin expression, cut-off level and WHO grade.

Publication bias was first investigated by Funnel plots and then performed for each of the pooled study groups using the Begg's test. All $p$ values were two-sided and the significance level was set at $5 \%$.

\section{Results}

The study inclusion procedure and study characteristics

The selection procedure of the eligible studies was presented in Fig. 1. In brief, a total of 1153 studies were identified from our initial electronic search. Of these, we eliminated 306 studies owing to overlapping data sets. Of which, 847 abstracts were considered relevant and full texts were reviewed in detail. By the end of the review 13 literatures on glioma [12-24] (9 CD133 and 6 nestin; 1,490 patients), meeting our inclusion criteria for metaanalysis, were left with sufficient data for extraction.

The baseline characteristics of the literatures enrolled were summarized in Tables 1 and 2. Thirty two studies were included in those studies including 19 studies investigated the association between CD133 expression and outcome of glioma patients and 13 studies for
Nestin. All studies were published between 2008 and 2014. Of these, the majority of the studies were executed in Europe $(n=23)$. Others were conducted in Asia $(n=8)$ and USA $(n=1)$. The total sample size from all studies was 1490 and the sample size was 24-379 patients and the range of medium age was 37.5-60.1 years. Of which, 13 studies evaluated grade II-III gliomas and 17 examined grade IV glioma. HRs and $95 \%$ CI for OS or PFS in 27 studies could be directly extracted and was produced by Kaplan-Meier analysis for the 5 remaining studies. The most frequently used cutoff values for the high versus low/ present versus absent expression of CD133 or Nestin were the median $(n=15)$ and values calculated by using several semiquantitative methods.

\section{CD133 expression and OS in gliomas}

A total of 11 studies were involved in the association between CD133 expression and OS of glioma patients, among which statistically significant heterogeneity was observed $\left(\mathrm{I}^{2}=77.8 \%\right)$. Therefore, a random model was applicable to calculate a pooled $\mathrm{HR}$ and $95 \% \mathrm{CI}$, the combined analysis showed that upon comparing patients with a low expression of CD133, patients possessing high CD133 expression had a significantly poorer OS $(\mathrm{HR}=1.69,95 \% \mathrm{CI}: 1.16$ to $2.47 ; P=.0006)$ (Fig. 2 ).

In order to avoid the influence of heterogeneity, further subgroup analyses were conducted and stratified based on the study origin, sample size, follow up period, patient age, test method, cut-off level and WHO grade. And the results showed that almost the subgroup

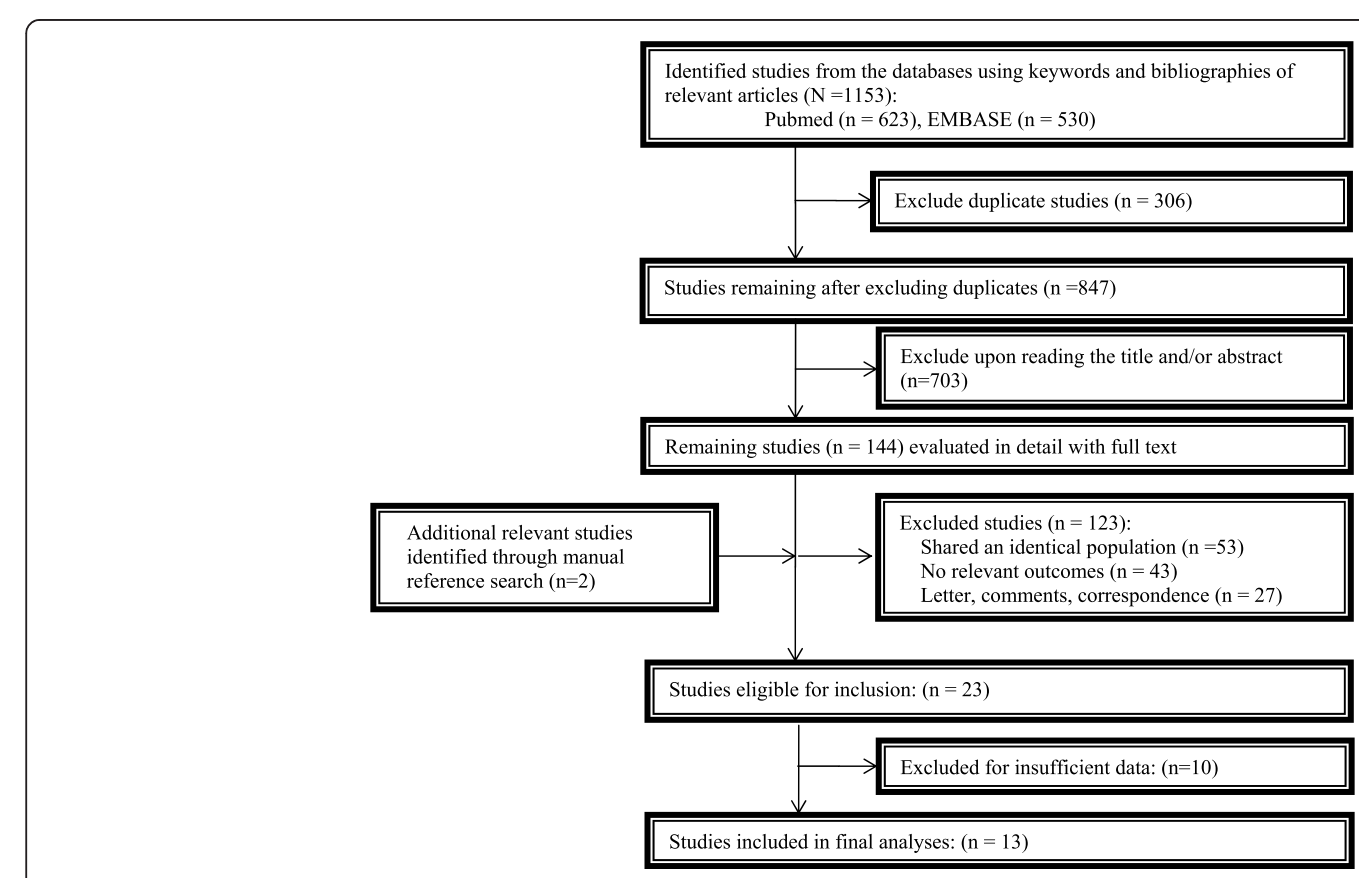

Fig. 1 Flowchart of study selection 
Table 1 General characteristics of included studies (about the relationships between CD133 expression and OS or PFS in glioma patients)

\begin{tabular}{|c|c|c|c|c|c|c|c|c|c|c|c|}
\hline First author & Year & $\begin{array}{l}\text { Origin } \\
\text { country }\end{array}$ & $\begin{array}{l}\text { No. of } \\
\text { patients }\end{array}$ & $\begin{array}{l}\text { Median/mean } \\
\text { age (year) }\end{array}$ & $\begin{array}{l}\text { WHO } \\
\text { grade }\end{array}$ & $\begin{array}{l}\text { Detect } \\
\text { method }\end{array}$ & Cut off level & $\begin{array}{l}\text { Survival } \\
\text { end points }\end{array}$ & Follow up period & Survival analysis & Adjusted variables \\
\hline Ardebili [10] & 2011 & Slovenia & 24 & mean 60 & IV & QRT-PCR & $\begin{array}{l}30000(-, 2- \\
\Delta \Delta C t>30.000)\end{array}$ & OS & NR & univariate (KM) & NR \\
\hline Kase [11] & 2013 & Estonia & 42 & $30-77$ & IV & $\mathrm{IHC}$ & median & OS & NR & multivariate & $\begin{array}{l}\text { Radiotherapy dose, Chemotherapy, Karnofsky } \\
\text { performance score }\end{array}$ \\
\hline \multirow[t]{2}{*}{ Kim [12] } & 2011 & Korea & 88 & mean 54.9 (13-80) & IV & $\mathrm{IHC}$ & $50 \%$ & OS & $\begin{array}{l}\text { mean } 13.9 \text { months } \\
(1-53)\end{array}$ & multivariate & $\begin{array}{l}\text { age, sex, Karnofsky performance scale (KPS) } \\
\text { score, extent of removal, chemoradiotherapeutic } \\
\text { modality, temozolomide modality, after } \\
\text { temozolomide therapy and stem cell marker } \\
\text { expression }\end{array}$ \\
\hline & & & & & & & & PFS & & & \\
\hline \multirow[t]{2}{*}{ Melguizo [13] } & 2012 & Italy & 75 & $24-81$ & IV & $\mathrm{IHC}$ & $25 \%$ & OS & NR & multivariate (KM) & NR \\
\hline & & & & & & & & PFS & & & \\
\hline \multirow[t]{2}{*}{ Metellus [14] } & 2011 & France & 48 & mean $60.1 \pm 9.2$ & IV & QPCR & 1.03 & OS & Median 18.9 months & multivariable & $\begin{array}{l}\text { Age, extent of surgery, MGMT status } \\
\text { (MethyLight) }\end{array}$ \\
\hline & & & & & & & & PFS & & & \\
\hline Shibahara [15] & 2013 & Japan & 112 & Media 57 (7-77) & IV & WB & $\begin{array}{l}\text { CD133/b-actin } \\
\text { ratio }=1\end{array}$ & OS & $\begin{array}{l}\text { Median } 25.7 \text { months } \\
(3-152)\end{array}$ & multivariable & $\begin{array}{l}\text { Ki67 LI ( } \geq 35 \%) \text {, 9p homozygous deletion and } \\
10 q \text { loss }\end{array}$ \\
\hline \multirow[t]{2}{*}{ Shin [16] } & 2013 & Korea & 67 & NR & IV & $\mathrm{IHC}$ & $50 \%$ & OS & NR & multivariable & status \\
\hline & & & & & & & & PFS & & & \\
\hline \multirow[t]{2}{*}{ Zeppernik [17] } & 2008 & Germany & 48 & NR & $\|-\| \|$ & $\mathrm{IHC}$ & $1 \%$ & OS & $\begin{array}{l}\text { mean } 86 \text { months } \\
( \pm 39)\end{array}$ & multivariate & age, WHO grade and extent of resection \\
\hline & & & & & & & & PFS & & & \\
\hline \multirow[t]{2}{*}{ Dahlrot [18] } & 2014 & Denmark & 25 & NR & $\|$ & IF & median & OS & Media 12 months & multivariate & age, performance status (PS) and IDH1 status \\
\hline & & & & & & & & PFS & & & \\
\hline \multirow[t]{2}{*}{ Dahlrot [18] } & 2014 & Denmark & 26 & NR & III & IF & median & OS & Media 12 months & multivariate & age, performance status (PS) and IDH1 status \\
\hline & & & & & & & & PFS & & & \\
\hline \multirow[t]{2}{*}{ Dahlrot [18] } & 2014 & Denmark & 185 & NR & IV & IF & median & OS & Media 12 months & multivariate & age, performance status (PS) and IDH1 status \\
\hline & & & & & & & & PFS & & & \\
\hline
\end{tabular}


Table 2 General characteristics of included studies (about the relationships between Nestin expression and OS or PFS in glioma patients)

\begin{tabular}{|c|c|c|c|c|c|c|c|c|c|c|c|}
\hline First author & Year & $\begin{array}{l}\text { Origin } \\
\text { country }\end{array}$ & $\begin{array}{l}\text { No. of } \\
\text { patients }\end{array}$ & $\begin{array}{l}\text { Median/mean } \\
\text { age (year) }\end{array}$ & $\begin{array}{l}\text { WHO } \\
\text { grade }\end{array}$ & $\begin{array}{l}\text { Detect } \\
\text { method }\end{array}$ & $\begin{array}{l}\text { Cut off } \\
\text { level }\end{array}$ & $\begin{array}{l}\text { Survival end } \\
\text { points }\end{array}$ & Follow up period & Survival analysis & Adjusted variables \\
\hline Hatanpa [19] & 2014 & USA & 50 & $\begin{array}{l}\text { median } 37.5 \text { years } \\
(20-66)\end{array}$ & $\|-1\|$ & $\mathrm{IHC}$ & median & OS & 4.3 year & multivariate $(\mathrm{KM})$ & $\begin{array}{l}\text { nestin, IDH, WHO grade, oligodendroglioma } \\
\text { component (astrocytoma or oligoastrocytoma), } \\
\text { MIB-1, age, sex, extent of resection and type of } \\
\text { adjuvant, therapy }\end{array}$ \\
\hline \multirow[t]{2}{*}{ Milde [20] } & 2012 & Russia & 379 & NR & $\|-1\|$ & $\mathrm{IHC}$ & $50 \%$ & OS & median 53 months & multivariate & $\begin{array}{l}\text { cytogenetic group only, or cytogenetic } \\
\text { group and posterior fossa group }\end{array}$ \\
\hline & & & & & & & & PFS & & & \\
\hline wan [21] & 2011 & Germany & 283 & NR & II-IV & $\mathrm{IHC}$ & median & OS & Mean $11.21 \pm 4.26$ years & multivariate & $\begin{array}{l}\text { WHO grade, patient age at diagnosis and } \\
\text { extent of resection }\end{array}$ \\
\hline \multirow[t]{2}{*}{ Kim [12] } & 2011 & Korea & 88 & $\begin{array}{l}\text { mean } 54.9 \text { years } \\
(13-80)\end{array}$ & IV & $\mathrm{IHC}$ & $50 \%$ & OS & mean $13.9(1-53)$ months & multivariate & $\begin{array}{l}\text { age, sex, KPS, extent of removal, } \\
\text { chemoradiotherapeutic modality, } \\
\text { temozolomide modality, after temozolomide } \\
\text { therapy and stem cell marker expression }\end{array}$ \\
\hline & & & & & & & & PFS & & & \\
\hline Arai [22] & 2012 & Japan & 64 & $\begin{array}{l}\text { median } 55 \text { years } \\
(11-79)\end{array}$ & III-IV & $\mathrm{IHC}$ & $60 \%$ & OS & 1-67 months & KM & NR \\
\hline \multirow[t]{2}{*}{ Dahlrot [18] } & 2014 & Denmark & 25 & NR & $\|$ & IF & median & OS & Media 12 months & multivariate & age, performance status (PS) and IDH1 status \\
\hline & & & & & & & & PFS & & & \\
\hline \multirow[t]{2}{*}{ Dahlrot [18] } & 2014 & Denmark & 26 & NR & III & IF & median & OS & Media 12 months & multivariate & age, performance status (PS) and IDH1 status \\
\hline & & & & & & & & PFS & & & \\
\hline Dahlrot [18] & 2014 & Denmark & 185 & NR & IV & IF & median & OS & Media 12 months & multivariate & age, performance status (PS) and IDH1 status \\
\hline
\end{tabular}




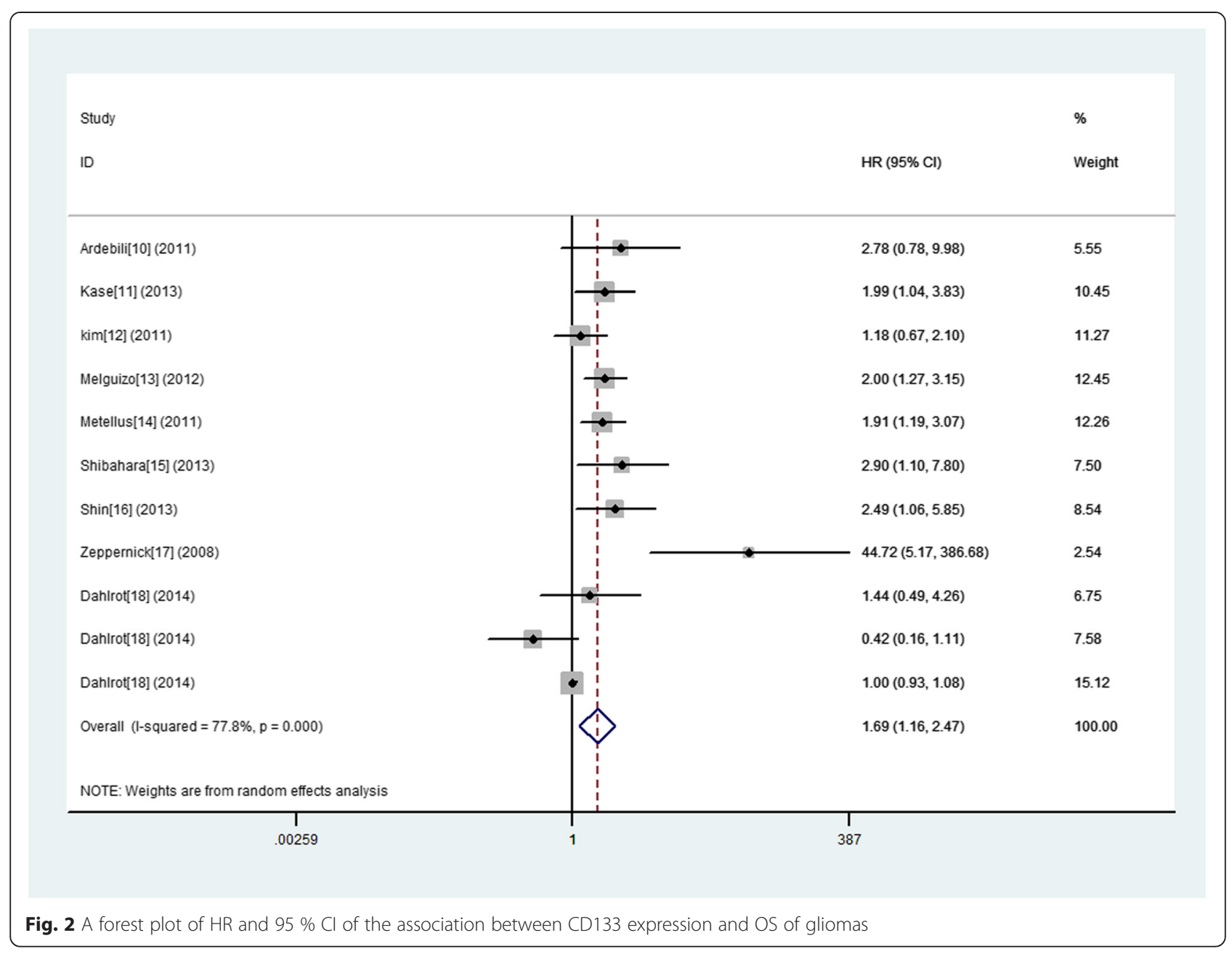

analysis with origin country did not alter the prognostic role of glioma in OS substantially. And, increased expression of CD133 predicted a significantly worse OS in following subgroups including sample size $\leq 50$, follow up period > media 12 months or no referred median/mean age referred, IHC test and cut-off level not median. However, we did not discover any significant association in other subgroups (Table 3). Even more important, when in subtotal analysis stratified by WHO grade of glioma, 8 studies of WHO IV glioma exhibited a significant association between increased expression of CD133 and poor OS (HR 1.73; $95 \% \mathrm{CI}$, $\left.1.20-2.50, p=0.004 \mathrm{I}^{2}=76.3\right)$. While, we did not find any significant association in subgroups of WHO II-III giomas (HR 2.38; $95 \% \mathrm{CI}, 0.30-18.82, p=0.441 \mathrm{I}^{2}=87.0$ ).

Regarding the publication bias in the studies, we found no funnel plot asymmetry. Furthermore, Begger's test was applied to provide statistical evidence for funnel plot symmetry. As expected, the $P$ value of Begger's test was 0.350 (Fig. 3). Hence, there was no evidence for significant publication bias in the meta-analysis.

\section{CD133 expression and PFS in gliomas}

Eight studies provided information concerning the association between CD133 expression and PFS of glioma patients. Similarly, a random model was applicable to calculate a pooled $\mathrm{HR}$ and $95 \% \mathrm{CI}$, since significant heterogeneity was observed in the pooled studies $\left(\mathrm{I}^{2}=\right.$ $80.5 \%)$. The combined analysis exhibited a significant association between increased expression of CD133 and poor PFS (HR 1.73; $95 \% \mathrm{CI}, 1.86-2.83, p=0.027$ ) (Fig. 4).

Further subgroup analyses were conducted and stratified based on the study origin, sample size, follow up period, patient age, test method, cut-off level and WHO grade. And the results show that increased expression of CD133 predicted a significantly worse OS in following subgroups including sample size $\leq 50$, follow up period $>$ media 12 months or no referred median/mean age referred, IHC test and cut-off level not median. However, we did not discover any significant association in other subgroups (Table 3). Similarly, the results in subtotal analysis stratified by WHO grade of glioma showed that 
Table 3 Subgroup analyses of the relationships between CD133 ovexpression and overall survival or progression-free-survival

\begin{tabular}{|c|c|c|c|c|c|c|}
\hline \multirow{2}{*}{$\begin{array}{l}\text { Comparison } \\
\text { variables }\end{array}$} & \multicolumn{3}{|l|}{ Overall survival } & \multicolumn{3}{|c|}{ Progression-free survival } \\
\hline & $\begin{array}{l}\text { Number of studies, } \\
\text { Heterogeneity } \\
\left(1^{2} \text { statistics; \%) }\right.\end{array}$ & HR $95 \%$ Cl, $P$ value & $\begin{array}{l}\text { Interaction, } \\
P \text { value }\end{array}$ & $\begin{array}{l}\text { Number of studies, } \\
\text { Heterogeneity } \\
\left(I^{2} \text { statistics; \%) }\right.\end{array}$ & HR $95 \% \mathrm{Cl}, P$ value & $\begin{array}{l}\text { Interaction, } \\
P \text { value }\end{array}$ \\
\hline Total & $11(77.8)$ & $1.69(1.16-2.47), 0.006$ & NA & $8(68.2)$ & $1.64(1.12-2.39), 0.010$ & NA \\
\hline \multicolumn{7}{|l|}{ Origin country } \\
\hline Europe & $8(81.0)$ & $1.63(1.03-2.61), 0.039$ & 0.030 & $6(76.5)$ & $1.74(1.06-2.83), 0.027$ & 0.579 \\
\hline Asian & $3(42.5)$ & $1.85(1.02-3.35), 0.044$ & & $2(0.0)$ & $1.37(0.86-2.18), 0.188$ & \\
\hline \multicolumn{7}{|l|}{ Sample size } \\
\hline$>50$ & $4(77.4)$ & $1.45(0.91-2.31), 0.116$ & 0.000 & $3(0.0)$ & $1.37(1.01-1.73), 0.009$ & 0.092 \\
\hline$\leq 50$ & $7(67.6)$ & $1.94(1.07-3.54), 0.030$ & & $5(77.0)$ & $1.99(0.94-4.22), 0.073$ & \\
\hline \multicolumn{7}{|l|}{ Follow up period } \\
\hline $1,>$ media 12 months & $4(74.1)$ & $2.48(1.13-5.45), 0.024$ & 0.000 & $3(86.7)$ & $2.64(0.98-7.11), 0.054$ & 0.060 \\
\hline $2, \leq$ media 12 months & $3(43.0)$ & $0.90(0.54-1.49), 0.678$ & & $3(0.0)$ & $1.12(0.79-1.57), 0.530$ & \\
\hline 3,No Referreed & $4(0)$ & $2.11(1.52-2.93), 0.000$ & & $2(0.0)$ & $1.64(1.19-2.27), 0.003$ & \\
\hline \multicolumn{7}{|l|}{ Median/mean age y } \\
\hline Referred & $6(0.0)$ & $1.85(1.45-2.37), 0.000$ & 0.000 & $3(0.0)$ & $1.59(1.24-2.04), 0.000$ & 0.713 \\
\hline No Referred & $5(79.8)$ & $1.57(0.70-3.55), 0.274$ & & $5(80.8)$ & $1.79(0.81-3.97), 0.153$ & \\
\hline \multicolumn{7}{|l|}{ Test method } \\
\hline $\mathrm{IHC}$ & $5(64.8)$ & $2.16(1.25-3.73), 0.006$ & 0.000 & $4(80.9)$ & $2.25(1.11-4.58), 0.025$ & 0.122 \\
\hline Others & $6(71.2)$ & $1.37(0.85-2.22), 0.202$ & & $4(20.4)$ & $1.31(0.93-1.84), 0.122$ & \\
\hline \multicolumn{7}{|l|}{ Cut-off level } \\
\hline 1:median & $4(61.4)$ & 1.09 (0.66-1.79) 0.748 & 0.000 & $3(0.0)$ & $1.12(0.79-1.57), 0.530$ & 0.024 \\
\hline 2:others & $7(51.3)$ & $2.17(1.44-3.27), 0.000$ & & $5(74.5)$ & $2.07(1.25-3.43), 0.005$ & \\
\hline \multicolumn{7}{|l|}{ WHO grade } \\
\hline IV & $8(76.3)$ & $1.73(1.20-2.50), 0.004$ & 0.915 & $5(0.00)$ & $1.46(1.19-1.80), 0.000$ & 0.143 \\
\hline$\|-\mid\|$ & $3(87.0)$ & $2.38(0.30-18.82), 0.411$ & & $3(88.1)$ & $2.17(0.42-11.28), 0.355$ & \\
\hline
\end{tabular}

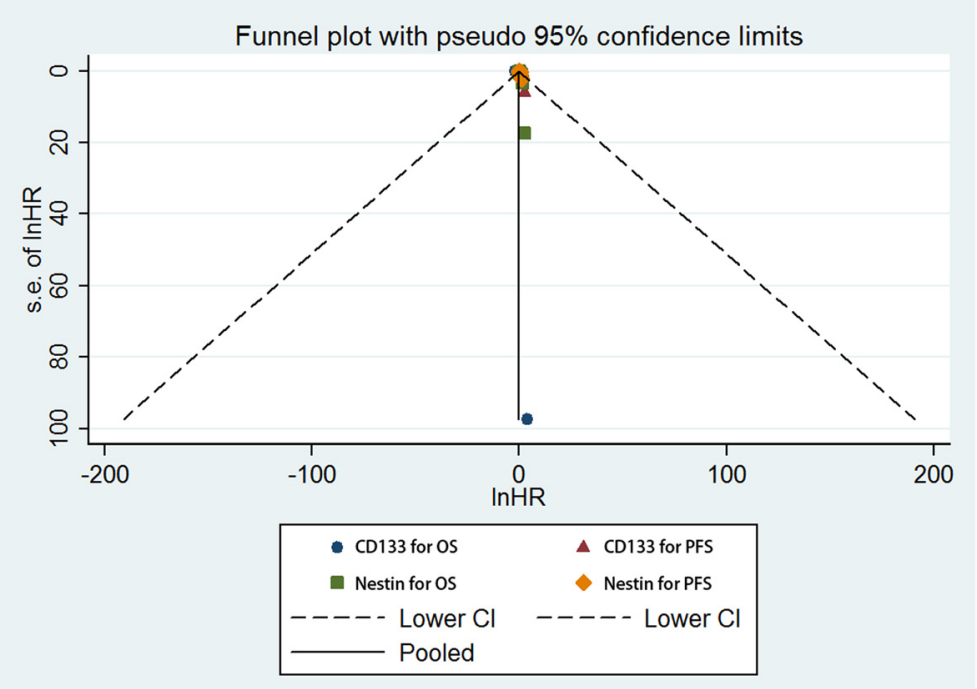

Fig. 3 A Begg's funnel plot for the publication bias test of the CD133 or Nestin overexpression and OS or PFS of human gliomas 


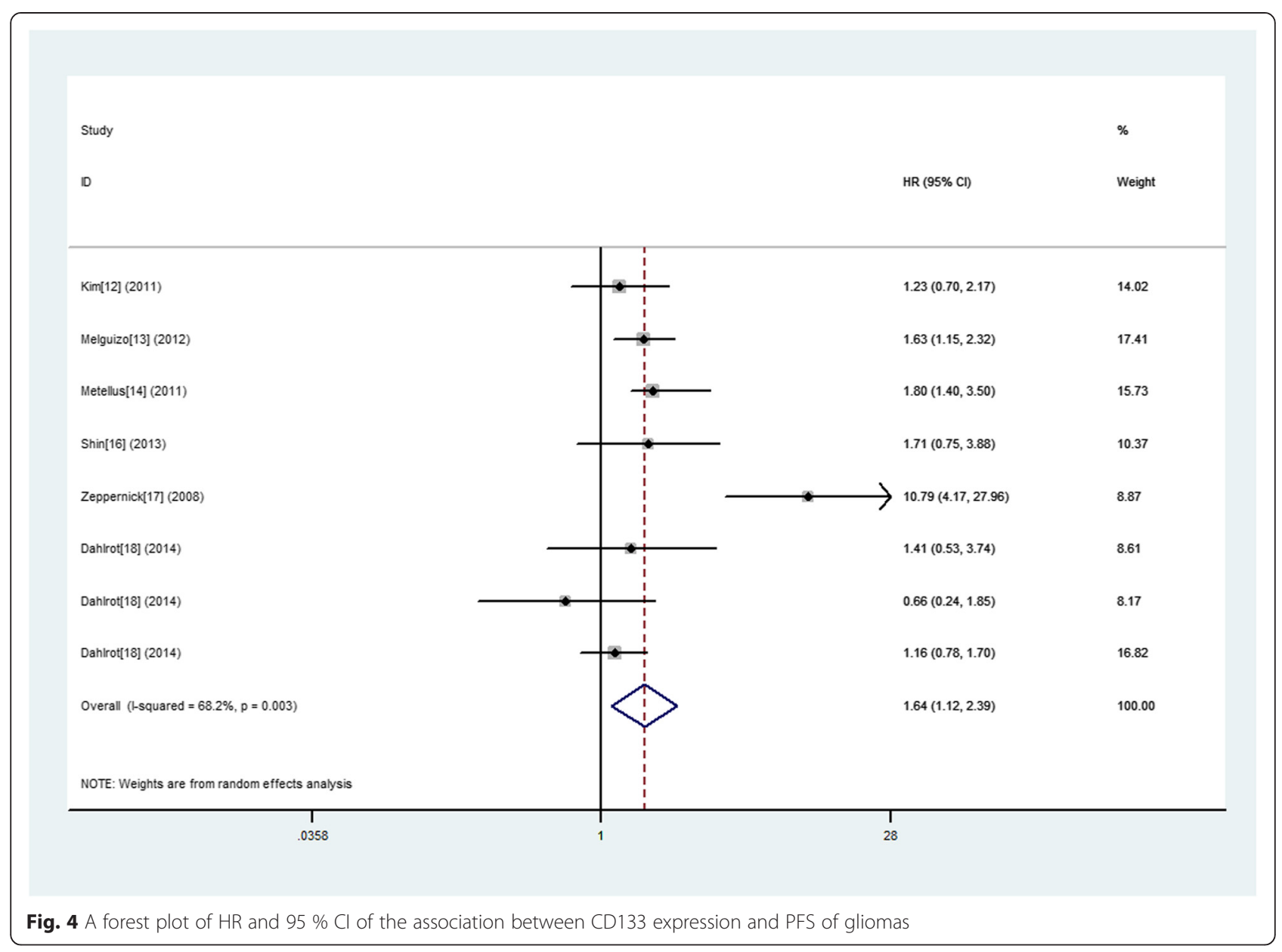

five studies of WHO IV glioma exhibited a significant association between increased expression of CD133 and poor OS (HR 1.46; $95 \% \mathrm{CI}, 1.19-1.80, p=0.000 \mathrm{I}^{2}=$ 0.00 ). However, we did not find any significant association in subgroups of WHO II-III giomas (HR 2.17; $95 \%$ CI, $0.42-11.28, p=0.355 \mathrm{I}^{2}=88.1$ ).

At the same time, no funnel plot asymmetry was found in the studies and the Begger's test did not show any evidence of publication bias $(P=0.902$; Fig. 3$)$.

\section{Nestin expression and OS in gliomas}

Eight eligible studies provided the estimation of the HR and $95 \% \mathrm{CI}$ for the correlation between Nestin expression and OS of glioma patients, among which statistically significant heterogeneity was observed $\left(\mathrm{I}^{2}=75.8 \%\right)$. Therefore, a random model was applicable to calculate a pooled HR and $95 \% \mathrm{CI}$ and the combined analysis showed that upon comparing patients with a low expression of Nestin, patients with high Nestin expression had a significantly poorer $\mathrm{OS}(\mathrm{HR}=1.75,95 \% \mathrm{CI}: 1.19$ to 2.58; $P=0.004$ ) (Fig. 5).
The subgroup analyses were conducted and stratified based on the study origin, sample size, follow up period, patient age, test method, cut-off level and WHO grade. And the results showed that increased expression of CD133 predicted a significantly worse OS in following subgroups including sample size $\leq 50$, follow up period > media 12 months or no referred, median/mean age referred, IHC test and cut-off level not median. However, we did not discover any significant association in other subgroups (Table 4). Even more important, when in subtotal analysis stratified by WHO grade of glioma, four studies of WHO II-III glioma exhibited a significant association between increased expression of Nestin and poor OS (HR 3.11; $95 \% \mathrm{CI}, 1.45-6.67, p=0.004 \mathrm{I}^{2}=57.2$ ). However, we did not discover any significant association in subgroups of WHO IV giomas (HR 1.09; 95 \% CI, 0.831.44, $p=0.518 \mathrm{I}^{2}=0.000$ ).

The publication bias in the studies was conducted, the funnel plot asymmetry was not found. Then, we applied Begger's test to provide statistical evidence for funnel plot symmetry. As expected, the $P$ value of Begger's test 


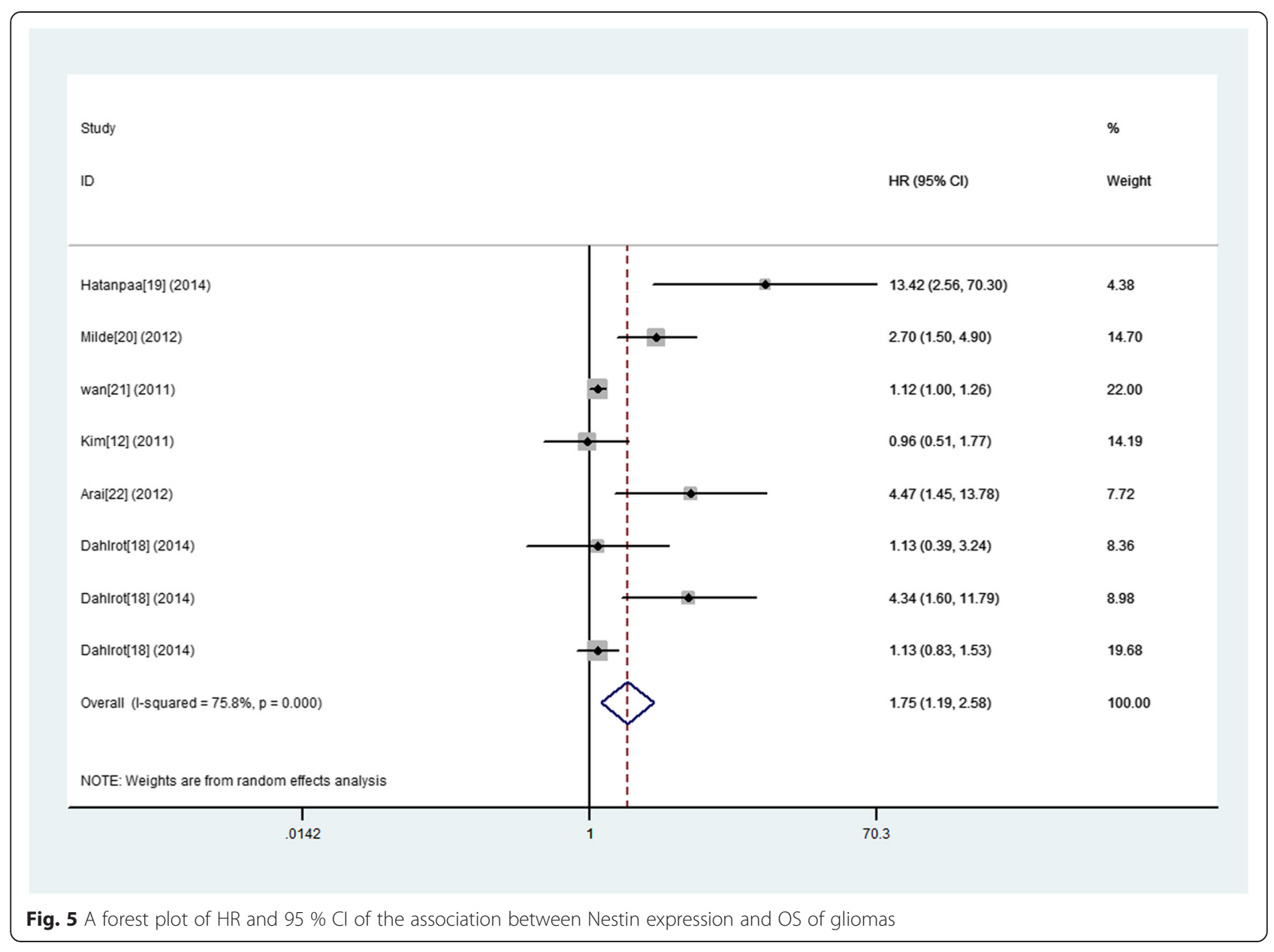

was 0.266 (Fig. 3). Hence, there was no evidence for significant publication bias in the meta-analysis.

\section{Nestin expression and PFS in gliomas}

The combined analysis of the five studies did not exhibit a significant association between increased expression of Nestin and poor PFS (HR 1.55; 95 \% CI, 0.96-2.51, $p=$ 0.074) (Fig. 6).

Further subgroup analyses were conducted and stratified based on the study origin, sample size, follow up period, patient age, test method, cut-off level and WHO grade. And the results showed that increased expression of Nestin predicted a significantly worse OS in following subgroups including sample size $\leq 50$, follow up period $>$ media 12 months or no referred, median/mean age referred, IHC test and cut-off level not median. However, we did not discover any significant association in other subgroups (Table 4). Similarly, the results in subtotal analysis stratified by WHO grade of glioma showed that two studies of WHO IV glioma exhibited a significant association between increased expression of Nestin and poor OS (HR 2.34; $95 \%$ CI, 1.68-3.27, $\left.p=0.000 \mathrm{I}^{2}=0.000\right)$.
However, we did not find any significant association in subgroups of WHO II-III giomas (HR 1.04; 95 \% CI, 0.77-1.41, $\left.p=0.808 \mathrm{I}^{2}=0.000\right)$.

At the same time, no funnel plot asymmetry was found in the studies and the Begger's test did not show any evidence of publication bias $(P=0.221$; Fig. 3$)$.

\section{Discussion}

Cancer stem cells (CSC), a small portion of cell population with the characteristics of stem cells, are present in the tumor tissue. It is the root to form the tumor cells with different degree of differentiation because of a capacity of self-renewing and the multi-directional differentiative potential $[1,3,25]$. At the earliest, CSC is found in the blood system tumors [26]. Recently, with the development of flow cytometry and in vitro tumor formation technology, cancer stem cells have been isolated and identified in a variety of solid tumors [27, 28]. The proposed cancer stem cell theory makes people have a new understanding on the biological behavior of tumors: the tumor is not only a genetic disease, but also a disease of stem cells. Stem cells become cancer stem cells after 
Table 4 Subgroup analyses of the relationships between Nestin expression and overall survival or progression-free-survival

\begin{tabular}{|c|c|c|c|c|c|c|}
\hline \multirow{2}{*}{$\begin{array}{l}\text { Comparison } \\
\text { variables }\end{array}$} & \multicolumn{3}{|l|}{ Overall survival } & \multicolumn{3}{|c|}{ Progression-free survival } \\
\hline & $\begin{array}{l}\text { Number of studies, } \\
\text { Heterogeneity } \\
\left(I^{2} \text { statistics; \%) }\right.\end{array}$ & HR $95 \%$ Cl, $P$ value & $\begin{array}{l}\text { Interaction, } \\
P \text { value }\end{array}$ & $\begin{array}{l}\text { Number of studies, } \\
\text { Heterogeneity } \\
\left(I^{2} \text { statistics; \%) }\right.\end{array}$ & HR $95 \%$ Cl, $P$ value & $\begin{array}{l}\text { Interaction, } \\
P \text { value }\end{array}$ \\
\hline Total & $8(75.8)$ & $1.75(1.19-2.58), 0.004$ & NA & $5(71.5)$ & $1.55(0.96-2.51), 0.074$ & NA \\
\hline \multicolumn{7}{|l|}{ Origin country } \\
\hline Europe & $5(73.1)$ & $1.52(1.04-2.21), 0.029$ & 0.014 & $4(74.1)$ & $1.76(0.98-3.14), 0.057$ & 0.142 \\
\hline Asian & $2(81.8)$ & $1.92(0.43-8.62), 0.393$ & & $1(\mathrm{NA})$ & $1.55(0.96-2.51), 0.973$ & \\
\hline USA & $1(\mathrm{NA})$ & $13.42(2.56-70.34), 0.002$ & & & & \\
\hline \multicolumn{7}{|l|}{ Sample size } \\
\hline$>50$ & $5(71.6)$ & $1.41(1.00-1.98), 0.051$ & 0.005 & $3(82.6)$ & $1.39(0.77-2.50), 0.277$ & 0.322 \\
\hline$\leq 50$ & $3(71.2)$ & $3.61(0.99-13.17), 0.052$ & & $2(36.5)$ & $2.14(0.85-5.35), 0.105$ & \\
\hline \multicolumn{7}{|l|}{ Follow up period } \\
\hline $1,>$ media 12 months & $2(68.7)$ & $4.96(1.08-22.78), 0.040$ & 0.001 & $1(\mathrm{NA})$ & $2.40(1.60-3.40), 0.000$ & 0.008 \\
\hline $2, \leq$ media 12 months & $3(68.8)$ & $1.64(0.74-3.67), 0.225$ & & $3(55.4)$ & $1.49(0.76-2.94), 0.246$ & \\
\hline 3,No Referreed & $3(66.8)$ & $1.35(0.77-2.38), 0.300$ & & $1(\mathrm{NA})$ & $1.01(0.57-1.79), 0.973$ & \\
\hline \multicolumn{7}{|l|}{ Median/mean age y } \\
\hline Referred & $3(83.4)$ & $3.36(0.72-15.61), 0.123$ & 0.154 & $1(\mathrm{NA})$ & $1.01(0.57-1.80), 0.973$ & 0.142 \\
\hline No Referred & $5(75.8)$ & $1.52(1.04-2.21), 0.029$ & & $4(74.7)$ & $1.76(0.98-3.14), 0.057$ & \\
\hline \multicolumn{7}{|l|}{ Test method } \\
\hline $\mathrm{IHC}$ & $5(82.1)$ & $2.11(1.10-4.04), 0.025$ & 0.671 & $2(83.6)$ & $1.60(0.69-3.73), 0.275$ & 0.063 \\
\hline Others & $3(68.8)$ & $1.64(0.74-3.67), 0.225$ & & $3(55.4)$ & $1.49(0.76-2.51), 0.246$ & \\
\hline \multicolumn{7}{|l|}{ Cut-off level } \\
\hline 1:median & $5(74.1)$ & $1.55(1.00-2.42), 0.050$ & 0.021 & $3(55.4)$ & $1.49(0.76-2.94), 0.246$ & 0.063 \\
\hline 2:others & $3(75.6)$ & $2.10(0.88-5.00), 0.093$ & & $2(83.6)$ & $1.60(0.69-3.73), 0.275$ & \\
\hline \multicolumn{7}{|l|}{ WHO grade } \\
\hline IV & $2(0.0)$ & $1.09(0.83-1.44), 0.518$ & 0.000 & $2(0.00)$ & $1.04(0.77-1.41), 0.808$ & 0.000 \\
\hline$\|-I I$ & $4(57.2)$ & $3.11(1.45-6.67), 0.004$ & & $3(0.00)$ & $2.34(1.68-3.27), 0.000$ & \\
\hline
\end{tabular}

gene mutations, which is the root of tumor recurrence and metastasis [29].

Glioma stem cells can be sorted by finding its markers in order to conducted the targeted chemotherapy for glioma stem cells, which can effectively improve the specificity of chemotherapy and reduce the side effects on the normal engine body and cells, thereby finding a new breakthrough for cancer treatment [30]. Recently, the markers of glioma stem cell that are studied more than others include CD133, nestin, HMGA1, A2B5, etc. [31-34]. It has made some breakthroughs from the continuous in-depth study of these markers, but there is a lot of controversy.

At present, a number of studies have shown that glioma stem cell markers CD133 and Nestin are closely related to the prognosis of patients with glioma, but some individual studies show that there is no clear relationship between CD133, Nestin and the prognosis of patients with glioma. We used Meta-analysis to systematically evaluate the literatures on the relationship between the glioma stem cells markers Nestin, CD133 and the prognosis of patients with glioma in order to accurately and objectively evaluate the application value of $\mathrm{CDl} 33$ and Nestin in prognosis of glioma.

The current meta-analysis is the first to systematically estimate the association between cancer stem cell markers and glioma survival. In this study, the results showed that CSCs marker CD133 was associated with worse OS and PFS in glioma patients and Nestin was associated with worse OS but not PFS. Especially, subgroup analysis showed that the overexpression of CD133 had a more significant predictive value for glioma patients with WHO grade II-III, but Nestin for WHO grade IV.

Limitations of this study include: (1) the number of selected cases in the research is too few, especially only 


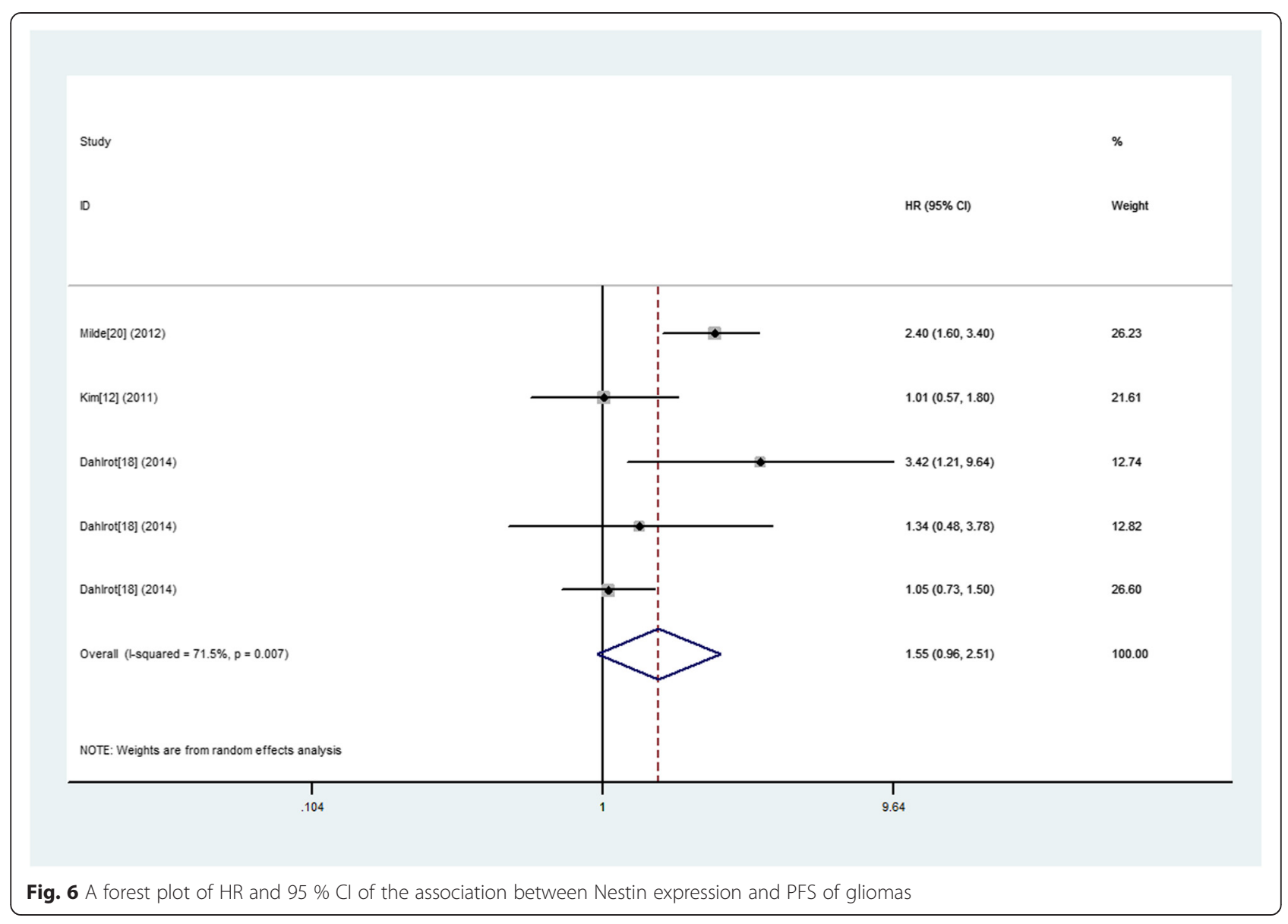

1490 cases. (2) Although this study has tried to collect all the relevant data, the potential publication bias is inevitable, some data may be missing. The missing information may reduce the reliability of $\mathrm{CDl} 33$ and Nestin expression as a prognostic indicator of glioma. (3) Although immunohistochemistry and RT-PCR are the detection methods for CDl33, Nestin protein and gene, there are still some differences. This article collected all relevant documents in protein and gene level, there may be some heterogeneity in the methods. (4) the criterion of positive decision for the selected CDl33 and Nestin is different (median, mean, $25 \%, 50 \%, 1 \%$, or 3 others), leading to the heterogeneity of studies. (5) Follow-up time is different. So the study used a random effects model and subgroup analysis to compensate for these deficiencies.

Above all, we found that high CDl33 expression may be independent risk factor for glioma patients' prognosis, especially WHO IV gliomas and high Nestin expression may be independent risk factor for glioma patients' prognosis with grade WHO II-III. Based on the current findings, assessing $\mathrm{CDl} 33$ and Nestin expression could provide better prognostic information for patients with glioma and be used as a novel therapeutic target. Further large-scale cohort studies are needed to validate our results.

\section{Competing interests}

All the authors declare that they have no competing interests.

\section{Authors' contributions}

WB, SC and FF carried out the electronic and manual searches. XL and WB independently inspected all candidate articles and conducted study selection. XL and GM conducted data extraction. XL participated in the design of the study and performed the statistical analysis. $\mathrm{XL}$ conceived of the study and participated in its design and coordination and the drafted the manuscript. All authors read and approved the final manuscript.

\section{Acknowledgment}

The study was sponsored by the Natural Science Program of Zhejiang Department of Finance (No.: LY12H16032) and Youth Scientific Innovation Foundation of Zhejiang Cancer Hospital (No.: QN201402).

Received: 13 March 2015 Accepted: 6 May 2015

Published online: 14 May 2015

\section{References}

1. Stupp R, Tonn JC, Brada M, Pentheroudakis G. High-grade malignant glioma: ESMO Clinical Practice Guidelines for diagnosis, treatment and follow-up. Ann Oncol. 2010;21 Suppl 5:v190-3.

2. Huse JT, Aldape KD. The evolving role of molecular markers in the diagnosis and management of diffuse glioma. Clin Cancer Res. 2014;20:5601-11. 
3. Dontu G, Liu S, Wicha MS. Stem cells in mammary development and carcinogenesis: implications for prevention and treatment. Stem Cell Rev. 2005; 1:207-13.

4. Donnenberg VS, Donnenberg AD. Multiple drug resistance in cancer revisited: the cancer stem cell hypothesis. J Clin Pharmacol. 2005;45:872-7.

5. Niero EL, Rocha-Sales B, Lauand C, Cortez BA, de Souza MM, Rezende-Teixeira P, et al. The multiple facets of drug resistance: one history, different approaches. J Exp Clin Cancer Res. 2014;33:37.

6. Singh SK, Clarke ID, Terasaki M, Bonn VE, Hawkins C, Squire J, et al. Identification of a cancer stem cell in human brain tumors. Cancer Res. 2003;63:5821-8.

7. Suetsugu A, Nagaki M, Aoki H, Motohashi T, Kunisada T, Moriwaki H. Characterization of CD133+ hepatocellular carcinoma cells as cancer stem/progenitor cells. Biochem Biophys Res Commun. 2006;351:820-4.

8. Ferrandina G, Bonanno G, Pierelli L, Perillo A, Procoli A, Mariotti A, et al. Expression of CD133-1 and CD133-2 in ovarian cancer. Int J Gynecol Cancer. 2008;18:506-14.

9. Kojima M, Ishii G, Atsumi N, Fujii S, Saito N, Ochiai A. Immunohistochemical detection of CD133 expression in colorectal cancer: a clinicopathological study. Cancer Sci. 2008;99:1578-83.

10. Eramo A, Lotti F, Sette G, Pilozzi E, Biffoni M, Di Virgilio A, et al. Identification and expansion of the tumorigenic lung cancer stem cell population. Cell Death Differ. 2008:15:504-14.

11. Zhang M, Song T, Yang L, Chen R, Wu L, Yang Z, et al. Nestin and CD133: valuable stem cell-specific markers for determining clinical outcome of glioma patients. J Exp Clin Cancer Res. 2008;27:85.

12. Ardebili SY, Zajc I, Gole B, Campos B, Herold-Mende C, Drmota S, et al. CD133/prominin1 is prognostic for GBM patient's survival, but inversely correlated with cysteine cathepsins' expression in glioblastoma derived spheroids. Radiol Oncol. 2011;45:102-15.

13. Kase M, Minajeva A, Niinepuu K, Kase S, Vardja M, Asser T, et al. Impact of CD133 positive stem cell proportion on survival in patients with glioblastoma multiforme. Radiol Oncol. 2013;47:405-10.

14. Kim KJ, Lee KH, Kim HS, Moon KS, Jung TY, Jung S, et al. The presence of stem cell marker-expressing cells is not prognostically significant in glioblastomas. Neuropathology. 2011;31:494-502.

15. Melguizo C, Prados J, Gonzalez B, Ortiz R, Concha A, Alvarez PJ, et al. MGMT promoter methylation status and MGMT and CD133 immunohistochemical expression as prognostic markers in glioblastoma patients treated with temozolomide plus radiotherapy. J Transl Med. 2012;10:250.

16. Metellus P, Nanni-Metellus I, Delfino C, Colin C, Tchogandjian A, Coulibaly B, et al. Prognostic impact of CD133 mRNA expression in 48 glioblastoma patients treated with concomitant radiochemotherapy: a prospective patient cohort at a single institution. Ann Surg Oncol. 2011;18:2937-45.

17. Shibahara I, Sonoda Y, Saito R, Kanamori M, Yamashita Y, Kumabe T, et al. The expression status of CD133 is associated with the pattern and timing of primary glioblastoma recurrence. Neuro Oncol. 2013;15:1151-9.

18. Shin JH, Lee YS, Hong YK, Kang CS. Correlation between the prognostic value and the expression of the stem cell marker CD133 and isocitrate dehydrogenase1 in glioblastomas. J Neurooncol. 2013;115:333-41.

19. Zeppernick F, Ahmadi R, Campos B, Dictus C, Helmke BM, Becker N, et al. Stem cell marker CD133 affects clinical outcome in glioma patients. Clin Cancer Res. 2008;14:123-9.

20. Dahlrot RH, Hansen S, Jensen SS, Schroder HD, Hjelmborg J, Kristensen BW Clinical value of CD133 and nestin in patients with glioma: a populationbased study. Int J Clin Exp Pathol. 2014;7:3739-51.

21. Hatanpaa KJ, Hu T, Vemireddy V, Foong C, Raisanen JM, Oliver D, et al. High expression of the stem cell marker nestin is an adverse prognostic factor in WHO grade II-III astrocytomas and oligoastrocytomas. J Neurooncol. 2014;117:183-9.

22. Milde T, Hielscher T, Witt H, Kool M, Mack SC, Deubzer HE, et al. Nestin expression identifies ependymoma patients with poor outcome. Brain Pathol. 2012;22:848-60.

23. Wan F, Herold-Mende C, Campos B, Centner FS, Dictus C, Becker N, et al. Association of stem cell-related markers and survival in astrocytic gliomas. Biomarkers. 2011;16:136-43.

24. Arai H, Ikota H, Sugawara K, Nobusawa S, Hirato J, Nakazato Y. Nestin expression in brain tumors: its utility for pathological diagnosis and correlation with the prognosis of high-grade gliomas. Brain Tumor Pathol. 2012:29:160-7.
25. Tomao F, Papa A, Rossi L, Strudel M, Vici P, Lo Russo G, et al. Emerging role of cancer stem cells in the biology and treatment of ovarian cancer: basic knowledge and therapeutic possibilities for an innovative approach. J Exp Clin Cancer Res. 2013;32:48.

26. Yin AH, Miraglia S, Zanjani ED, Almeida-Porada G, Ogawa M, Leary AG, et al. AC133, a novel marker for human hematopoietic stem and progenitor cells. Blood. 1997;90:5002-12.

27. Nosrati A, Naghshvar F, Khanari S. Cancer stem cell markers CD44, CD133 in primary gastric adenocarcinoma. Int J Mol Cell Med. 2014;3:279-86.

28. Di C, Zhao Y. Multiple drug resistance due to resistance to stem cells and stem cell treatment progress in cancer (Review). Exp Ther Med. 2015;9:289-93.

29. Allegra A, Alonci A, Penna G, Innao V, Gerace D, Rotondo F, et al. The cancer stem cell hypothesis: a guide to potential molecular targets. Cancer Invest. 2014;32:470-95.

30. Kong BH, Moon JH, Huh YM, Shim JK, Lee JH, Kim EH, et al. Prognostic value of glioma cancer stem cell isolation in survival of primary glioblastoma patients. Stem Cells Int. 2014;2014:838950.

31. Campos B, Herold-Mende CC. Insight into the complex regulation of CD133 in glioma. Int J Cancer. 2011;128:501-10.

32. Jin X, Jung JE, Beck S, Kim H. Cell surface Nestin is a biomarker for glioma stem cells. Biochem Biophys Res Commun. 2013;433:496-501.

33. Fan H, Guo H, Zhang IY, Liu B, Luan L, Xu S, et al. The different HMGA1 expression of total population of glioblastoma cell line U251 and glioma stem cells isolated from U251. Brain Res. 2011;1384:9-14.

34. Xu M, Yao Y, Hua W, Wu Z, Zhong P, Mao Y, et al. Mouse glioma immunotherapy mediated by A2B5+ GL261 cell lysate-pulsed dendritic cells. J Neurooncol. 2014;116:497-504.

\section{Submit your next manuscript to BioMed Central and take full advantage of:}

- Convenient online submission

- Thorough peer review

- No space constraints or color figure charges

- Immediate publication on acceptance

- Inclusion in PubMed, CAS, Scopus and Google Scholar

- Research which is freely available for redistribution

Submit your manuscript at www.biomedcentral.com/submit
C Biomed Central 